\title{
Gangguan Fungsi Hati pada Coronavirus Disease 2019
}

\author{
Tasha Salsabila, ${ }^{1}$ Bradley J. Waleleng, ${ }^{2}$ Karel Pandelaki ${ }^{2}$
}

\author{
${ }^{1}$ Program Studi Pendidikan Dokter Fakultas Kedokteran Universitas Sam Ratulangi, Manado, \\ Sulawesi Utara \\ ${ }^{2}$ Bagian Ilmu Penyakit Dalam Fakultas Kedokteran Universitas Sam Ratulangi, Manado, \\ Sulawesi Utara, Indonesia \\ E-mail: salsatasha@gmail.com
}

\begin{abstract}
The incidence and death rate of COVID-19 in North Sulawesi Province continues to increase and data regarding abnormal liver function in COVID-19 is not yet available. This study was aimed to obtain the liver function in COVID-19 patients. This was a literature review study using two databases, namely Pubmed and ClinicalKey. Keywords used were abnormal liver function AND COVID-19, elevated alanine aminotransferase AND COVID-19, elevated aspartate aminotransferase AND COVID-19, elevated gamma-glutamyl transferase AND COVID-19, elevated alkaline phosphatase AND COVID-19, elevated total bilirubin AND COVID-19. After being selected, 10 literatures were obtained based on inclusion and exclusion criteria. The results showed that increased liver function often occurred in cases of COVID-19, but the increase did not reach twice of the normal value. The most frequent increases were in GGT, followed by ALT and AST, total bilirubin, and the least was the increase in ALP. All literatures reported that increased liver function was more common in males, and in severe COVID-19 patients reported by eight literatures. Five literatures reported that elevated liver function increased mortality in COVID-19 cases. In conclusion, there are increases in ALT, AST, ALP, GGT, and total bilirubin levels in COVID-19 patients.
\end{abstract}

Keywords: abnormal liver function, COVID-19

\begin{abstract}
Abstrak: Angka kejadian dan angka kematian COVID-19 di Provinsi Sulawesi Utara terus bertambah sedangkan data mengenai gambaran gangguan fungsi hati pada COVID-19 belum tersedia. Penelitian ini bertujuan untuk mengetahui gambaran fungsi hati pada COVID-19. Jenis penelitian ialah literature review dengan pencarian data menggunakan dua database yaitu Pubmed dan ClinicalKey. Kata kunci yang digunakan yaitu abnormal liver function AND COVID-19, elevated alanine aminotransferase AND COVID-19, elevated aspartate aminotransferase AND COVID-19, elevated gamma-glutamyl transferase AND COVID-19, elevated alkaline phosphatase AND COVID-19, elevated total bilirubin AND COVID-19. Setelah diseleksi, didapatkan 10 literatur berdasarkan kriteria inklusi dan eksklusi. Penelitian ini mendapatkan bahwa peningkatan fungsi hati sering terjadi pada kasus COVID-19 namun peningkatannya tidak mencapai dua kali nilai normal. Peningkatan paling sering terjadi pada GGT, diikuti oleh ALT dan AST, bilirubin total, dan paling sedikit yaitu pada peningkatan ALP. Seluruh literatur melaporkan peningkatan fungsi hati lebih sering terjadi pada laki-laki dan pada kasus COVID-19 gejala berat dilaporkan oleh delapan literatur. Lima literatur melaporkan peningkatan fungsi hati meningkatkan mortalitas pada kasus COVID-19. Simpulan penelitian ini ialah, terdapat peningkatan kadar ALT, AST, ALP, GGT, dan bilirubin total pada penderita COVID-19.
\end{abstract}

Kata kunci: gangguan fungsi Hati, COVID-19

\section{PENDAHULUAN}

Coronavirus Disease 2019 (COVID-19) merupakan penyakit yang disebabkan oleh infeksi Severe Acute Respiratory Syndrome 
Coronavirus 2 (SARS-CoV-2). ${ }^{1}$ World Health Organization (WHO) melaporkan sampai dengan tanggal 30 November 2020 total kasus konfirmasi sebanyak 63.043.588 dengan 1.464.721 kematian di seluruh dunia (Case Fatality Rate (CFR) 2,3\%). ${ }^{2}$ Pada tanggal yang sama, Kemenkes $\mathrm{RI}^{3}$ melaporkan jumlah kasus konfirmasi COVID-19 di Indonesia sebanyak 538.883 kasus dengan 16.945 kasus kematian (CFR 3,1\%) dan pada Provinsi Sulawesi Utara dilaporkan sebanyak 6.904 kasus konfirmasi COVID19 dengan 245 kematian (CFR 3,5\%). ${ }^{4}$

Penyakit ini bermanifestasi secara primer sebagai infeksi saluran pernapasan, namun data penelitian menunjukkan bahwa COVID-19 harus dianggap sebagai penyakit sistemik yang melibatkan beberapa sistem, termasuk kardiovaskular, pernapasan, pencernaan, neurologis, sistem hematopoietik dan sistem imun. ${ }^{5}$ Manifestasi utama COVID-19 meliputi demam, batuk, lemah badan, dan sesak napas. ${ }^{1}$ Namun, terdapat penelitian yang melaporkan bahwa lebih dari setengah pasien menunjukkan gangguan fungsi hati yang bervariasi. ${ }^{6}$

Reseptor sel tempat terikatnya SARSCoV-2 ialah reseptor Angiotensin-Converting-Enzyme 2 (ACE-2), ekspresi reseptor ini ditemukan tidak hanya tinggi pada sel epitel alveolus tipe II namun juga pada sel saluran empedu (kolangiosit). Temuan ini menunjukkan bahwa virus ini dapat menginfeksi saluran empedu dan menyebabkan gangguan fungsi hati pada pasien. ${ }^{7}$

Sebuah penelitian di Cina menunjukkan bahwa dari 417 kasus COVID-19 didapatkan 318 (76,3\%) kasus memiliki gangguan fungsi hati dan sebanyak $90(21,5 \%)$ kasus mengalami kerusakan hati selama dirawat di rumah sakit. Gangguan fungsi hati menjadi lebih jelas setelah dua minggu perawatan, di mana 49 (23,4\%), $31(14,8 \%), 24$ (11,5\%), dan $51(24,4 \%)$ kasus masing-masing mengalami peningkatan kadar alanine aminotransferase (ALT), aspartat aminotransferase (AST), bilirubin total, dan gammaglutamil transferase (GGT) lebih dari tiga kali nilai normal. ${ }^{8}$

Angka kejadian dan angka kematian COVID-19 di Provinsi Sulawesi Utara terus bertambah dan data mengenai gambaran gangguan fungsi hati pada COVID-19 belum tersedia. Berdasarkan latar belakang tersebut, peneliti tertarik untuk melakukan penelitian literature review untuk membahas dan menelaah berbagai informasi ilmiah mengenai gangguan fungsi hati pada COVID-19.

\section{METODE PENELITIAN}

Penelitian ini berbentuk literature review. Pencarian literatur menggunakan dua database yaitu PubMed dan ClinicalKey dengan enam kata kunci yakni abnormal liver function AND COVID-19, elevated alanine aminotransferase AND COVID-19, elevated aspartate amino transferase AND COVID-19, elevated gamma-glutamyl transferase AND COVID19, elevated alkaline phosphatase AND COVID-19, dan elevated total bilirubin AND COVID-19. Berdasarkan kriteria inklusi dan eksklusi didapatkan 10 literatur fulltext yang dilakukan kajian.

\section{HASIL PENELITIAN}

Sepuluh literatur yang memenuhi kriteria inklusi dan eksklusi didapatkan setelah melalui tahap seleksi studi. Semua literatur diterbitkan pada tahun 2020 dengan delapan penelitian dilakukan di Cina sedangkan sisanya dilakukan di Perancis dan Italia. Studi desain yang digunakan pada seluruh literatur ini ialah retrospektif dengan tambahan satu literatur yang menggunakan studi cohort juga.

Puluhan hingga ratusan sampel terkonfirmasi COVID-19 termasuk dalam sampel penelitian sepuluh literatur tersebut. Rerata usia sampel yang mengalami pening-katan fungsi hati pada lima literatur didapatkan dari 44,5 hingga 66,5 tahun, sedangkan pada lima literatur lainnya data didapatkan berupa median yakni 54 hingga 62 tahun. Pada seluruh literatur, persentase peningkatan fungsi hati lebih tinggi pada laki-laki daripada perempuan.

Riwayat penyakit penyerta sampel dengan peningkatkan fungsi hati didapatkan bervariasi. Adanya riwayat penyakit diabetes dan hipertensi dilaporkan pada sembilan literatur, diikuti dengan adanya riwayat 
penyakit hati kronis yaitu dilaporkan pada tujuh literatur. Terdapat tiga literatur oleh Shao et al. ${ }^{9}$ Wang et al, ${ }^{12}$ dan Chu et al, ${ }^{17}$ yang mengeksklusi sampel dengan riwayat penyakit hati.

Tabel 1 memperlihatkan karakteristik gangguan fungsi hati pada masing-masing literatur. Data pemeriksaan fungsi hati pada seluruh literatur diambil pada saat pasien masuk rumah sakit namun pada satu literatur oleh Wang et al, ${ }^{12}$ dambil nilai tertinggi dari beberapa kali pemeriksaan ALT dan AST, dan untuk nilai indikator gangguan hati lainnya diambil pada saat yang bersamaan dengan nilai tersebut.

\section{BAHASAN}

Pada 10 literatur yang dikaji, peningkatan indikator gangguan hati dilaporkan terjadi pada seluruh literatur dengan empat literatur mendapatkan peningkatan tersebut terjadi pada lebih dari setengah jumlah sampel. Peningkatan didapatkan setidaknya terjadi pada usia lebih dari 44 tahun, dengan lima literatur melaporkan bahwa pada kelompok dengan abnormalitas fungsi hati secara bermakna berusia lebih tua daripada kelompok yang normal. Pada seluruh literatur, peningkatan fungsi hati lebih banyak terjadi pada laki-laki.

Lima literatur melaporkan, tidak ada perbedaan bermakna pada komorbiditas antara kelompok dengan fungsi hati yang normal dan abnormal, sedangkan, tiga literatur melaporkan terdapat perbedaan bermakna antara kelompok abnormal dan normal fungsi hati pada sampel dengan riwayat hipertensi, dua literatur pada sampel dengan penyakit jantung koroner, dua literatur pada sampel dengan penyakit hati; dan pada sampel dengan riwayat diabetes, penyakit paru kronis, penyakit ginjal kronis, dan kanker dilaporkan oleh masing-masing satu literatur.

Berdasarkan hasil penelitian dari literatur-literatur yang dikaji, delapan literatur melaporkan terjadi peningkatan pada ALT dan AST namun peningkatannya hanya satu kali dari nilai normal. Pada GGT, peningkatan dilaporkan oleh sembilan literatur dan peningkatannya tidak mencapai dua kali nilai normal. Pada nilai bilirubin total, dua literatur melaporkan terjadi peningkatan yang juga tidak mencapai dua kali nilai normal, dan terdapat satu literatur yang melaporkan kejadian peningkatan ALP yang hanya satu kali nilai normal.

Penelitian ini mendapatkan bahwa peningkatan paling sering terjadi pada GGT, kemudian diikuti oleh ALT dan AST, bilirubin total, dan ALP. Hal ini sejalan dengan penelitian systematic review dan meta-analysis yang dilaporkan oleh $\mathrm{Wu}$ et al, ${ }^{18}$ yang menemukan bahwa di antara indikator gangguan hati yang diamati saat MRS, abnormalitas paling tinggi terjadi pada GGT, diikuti oleh AST, ALT, TBIL, dan ALP. Selain itu, Kumar-M et al, ${ }^{19}$ juga melaporkan bahwa kelainan yang paling sering ditemukan ialah peningkatan GGT, kemudian diikuti oleh aminotransferase, bilirubin, dan ALP. Hasil penelitian ini menunjukkan bahwa peningkatan sering terjadi pada kasus COVID-19, walaupun peningkatan tidak mencapai dua kali nilai normal.

Dilaporkan oleh delapan literatur, peningkatan fungsi hati ditemukan secara bermakna lebih tinggi terjadi pada kasus COVID-19 yang berat. Selain itu, lima literatur juga melaporkan bahwa peningkatan fungsi hati secara bermakna meningkatkan risiko kematian pada kasus COVID19. Hal ini dilaporkan oleh $\mathrm{Wu}$ et al, ${ }^{18}$ yang juga menemukan bahwa abnormalitas fungsi hati berkaitan erat dengan tingkat keparahan dan prognosis pada pasien COVID-19. Hal yang sama ditemukan Kumar-M et al, ${ }^{19}$ yaitu abnormalitas fungsi hati terutama peningkatan GGT dan aminotransferase, sering terjadi pada pasien dengan COVID-19 dan dengan gejala berat.

Salah satu mekanisme terjadinya peningkatan fungsi hati dicurigai oleh karena efek hepatotoksik dari beberapa obat yang digunakan pada terapi pasien COVID-19, seperti klorokuin, makrolida, kuinolon, dan lopinavir/ritonavir. ${ }^{20}$ 
56 Medical Scope Journal (MSJ), Volume 2, Nomor 2, Januari-Juni 2021, hlm. 53-58

Tabel 1. Karakteristik gangguan hati pada sampel masing-masing literatur

\begin{tabular}{|c|c|c|c|c|c|}
\hline \multirow[t]{2}{*}{ No } & \multirow[t]{2}{*}{ Peneliti } & \multirow[t]{2}{*}{ Tempat } & \multicolumn{2}{|c|}{ Jumlah Sampel } & \multirow[t]{2}{*}{ Indikator gangguan hati } \\
\hline & & & Total & Abnormal & \\
\hline 1 & Shao et al. ${ }^{9}$ & Cina & 98 & - & $\begin{array}{ll}- & \text { Abnormal GGT: } 32(32,7 \%) \\
& \text { Mean } \pm \text { SD: 53,6 U/L } \pm 80,33\end{array}$ \\
\hline 2 & Zhang et al. ${ }^{10}$ & Cina & 218 & $79(36,2 \%)$ & $\begin{array}{l}\text { - Abnormal ALT: } 68(86,1 \%) \\
\text { Mean } \pm \text { SD: 69,74 U/L } \pm 178,37 \\
\text { - Abnormal AST: } 73(92,9 \%) \\
\text { Mean } \pm \text { SD: 72,29 U/L } \pm 269,68 \\
\text { - Abnormal GGT: } 45(57,0 \%) \\
\text { Mean } \pm \text { SD: 83,25 U/L } \pm 93,48\end{array}$ \\
\hline 3 & Meszaros et al. ${ }^{6}$ & Perancis & 234 & $\begin{array}{c}156 \\
(66,7 \%)\end{array}$ & $\begin{aligned} \text { - } & \text { Abnormal ALT: } \\
& \text { Mean } \pm \text { SD:47,2 U/L } \pm 31,7 \\
\text { - } & \text { Abnormal AST: } \\
& \text { Mean } \pm \text { SD: } 57 \mathrm{U} / \mathrm{L} \pm 37,4 \\
\text { - } & \text { Abnormal GGT: } \\
& \text { Mean } \pm \text { SD: } 106,6 \mathrm{U} / \mathrm{L} \pm 106,4\end{aligned}$ \\
\hline 4 & Guo et al. ${ }^{11}$ & Cina & 332 & $98(27,3 \%)$ & $\begin{aligned} \text { - } & \text { Abnormal ALT: } 52(15,7 \%) \\
& \text { Mean } \pm \text { SD: 64,5 U/L } \pm 22,4 \\
\text { - } & \text { Abnormal AST: } 55(16,6 \%) \\
& \text { Mean } \pm \text { SD: } 64,0 \text { U/L } \pm 34,6 \\
\text { - } & \text { Abnormal ALP: } 4(1,2 \%) \\
& \text { Mean } \pm \text { SD: } 140,5 \pm 14,2 \\
- & \text { Abnormal GGT: } 41(12,3 \%) \\
& \text { Mean } \pm \text { SD: } 116,1 \pm 57,7 \\
- & \text { Abnormal TBiL: } 23(6,9 \%) \\
& \text { Mean } \pm \text { SD: } 23,4 \pm 6,7\end{aligned}$ \\
\hline 5 & Wang et al. ${ }^{12}$ & Cina & 156 & $64(41 \%)$ & $\begin{aligned} \text { - } & \text { Abnormal ALT: } \\
& \text { Median (IQR): 50,0 (40,0-70,0) } \\
\text { - } & \text { Abnormal AST: } \\
& \text { Median (IQR): 45,5 (38.0-60.0) }\end{aligned}$ \\
\hline 6 & Chen LY et al. ${ }^{13}$ & Cina & 502 & $301(60 \%)$ & $\begin{aligned} \text { - } & \text { Abnormal ALT: } 124(41,4 \%) \\
& \text { Median (IQR): } 50,0(35,0-75,0) \\
\text { - } & \text { Abnormal AST: } 113(37,5 \%) \\
& \text { Median (IQR): 45,0 }(33,0-60,0) \\
- & \text { Abnormal GGT: } 127(42,2 \%) \\
& \text { Median (IQR): } 61,0(28,0-97,0)\end{aligned}$ \\
\hline 7 & Piano et al. ${ }^{14}$ & Italia & 565 & $\begin{array}{c}329 \\
(58,2 \%)\end{array}$ & $\begin{aligned} \text { - } & \text { Abnormal ALT: } 105(32 \%) \\
& \text { Median (IQR): } 44(28-64) \\
\text { - } & \text { Abnormal AST: } 144(44 \%) \\
& \text { Median (IQR): } 52(40-73) \\
\text { - } & \text { Abnormal GGT: } 111(34 \%) \\
& \text { Median (IQR): } 56(34-94)\end{aligned}$ \\
\hline 8 & Fu et al. ${ }^{15}$ & Cina & 482 & $\begin{array}{c}142 \\
(29,5 \%)\end{array}$ & $\begin{aligned} \text { - } & \text { Abnormal ALT: } 96(67,6 \%) \\
& \text { Median (IQR): } 66,5(51,0-88,5) \\
\text { - } & \text { Abnormal AST: } 98(69 \%) \\
& \text { Median (IQR): } 59.0(46.8-76.5) \\
\text { - } & \text { Abnormal GGT: } \\
& \text { Median (IQR): } 54,0(30,8-99,3) \\
\text { - } & \text { Abnormal TBiL: } 23(16,2 \%) \\
& \text { Median (IQR): } 22,9(21,8-29,8)\end{aligned}$ \\
\hline 9 & Chen $\mathrm{F}$ et al. ${ }^{16}$ & Cina & 830 & $\begin{array}{c}227 \\
(27,3 \%)\end{array}$ & $\begin{array}{c}\text { - Abnormal GGT: } 115(50,7 \%) \\
\text { Median (IQR): } 60,9(64,95)\end{array}$ \\
\hline 10 & Chu et al. ${ }^{17}$ & Cina & 838 & $\begin{array}{c}429 \\
(51,2 \%)\end{array}$ & $\begin{aligned} \text { - } & \text { Abnormal ALT: } \\
& \text { Median (IQR): } 49 \text { (32-71) } \\
\text { - } & \text { Abnormal AST: } \\
& \text { Median (IQR): } 44 \text { (31-59) } \\
\text { - } & \text { Abnormal GGT: } \\
& \text { Median (IQR): } 49 \text { (26-93) }\end{aligned}$ \\
\hline
\end{tabular}

ALT: alanine aminotransferase; AST: aspartate aminotransferase; ALP: alkaline phosphatase; GGT: gamma-glutamyl transferase; TBiL: bilirubin total. 
Wang et $\mathrm{al}^{12}$ melaporkan pengaruh penggunaan obat pada pasien COVID-19 dan tidak mendapatkan perbedaan bermakna pada penggunaan obat antiviral dan antibiotik antara kelompok dengan normal dan abnormal fungsi hati. Pada literatur oleh Chu et $\mathrm{al}^{17}$ dilaporkan bahwa terdapat hubungan antara penggunaan lopinavir/ ritonavir dan ribavirin dengan kejadian abnormalitas fungsi hati; lopinavir/ ritonavir secara bermakna meningkatkan kadar AST dan GGT; dan ribavirin secara bermakna menyebabkan sedikit peningkatan pada kadar ALP. Masih diperlukan penelitian lebih lanjut untuk memastikan penyebab terjadinya abnormalitas fungsi hati pada kasus COVID-19.

\section{SIMPULAN}

Terdapat peningkatan kadar ALT, AST, ALP, GGT, dan bilirubin total pada kasus COVID-19. Gangguan fungsi hati sering terjadi pada kasus COVID-19 dengan peningkatan yang tidak mencapai dua kali nilai normal, dan ditemukan lebih banyak terjadi pada kasus COVID-19 berat dan pada jenis kelamin laki-laki. Abnormalitas fungsi hati juga meningkatkan risiko kematian pada pasien COVID-19.

\section{Konflik Kepentingan}

Penulis menyatakan tidak terdapat konflik kepentingan dalam studi ini.

\section{DAFTAR PUSTAKA}

1. Direktorat Jenderal Percepatan dan Pengendalian. Pedoman Pencegahan dan Pengendalian Coronavirus Disease (COVID-19) (revisi ke-5). Jakarta: Kementerian Kesehatan RI, 2020.

2. World Health Organization. WHO Coronavirus Disease (COVID-19) Dashboard | WHO Coronavirus Disease (COVID19) Dashboard. Available from: https://covid19.who.int/

3. Kementerian Kesehatan RI. Info Infeksi Emerging Kementerian Kesehatan RI. Available from: https://covid19. kemkes.go.id/category/situasi-infeksiemerging/info-corona-virus/\#.X2F6r GczZQI

4. Dinas Kesehatan Provinsi Sulawesi Utara.
Kondisi epidemiologis Covid-19 Sulawesi Utara 15 September 2020 Website Resmi Dinkes Prov Sulut. Available from: https://dinkes. sulutprov. go.id/2020/11/30/kondisi-epidemio logis-covid-19-sulawesi-utara-30november-2020/

5. Terpos E, Ntanasis-Stathopoulos I, Elalamy I, Kastritis E, Sergentanis TN, Politou M, et al. Hematological findings and complications of COVID-19. Am J Hematol. 2020;95(7):834-47.

6. Meszaros M, Meunier L, Morquin D, Klouche $\mathrm{K}$, Fesler $\mathrm{P}$, Malezieux $\mathrm{E}$, et al. Abnormal liver tests in patients hospitalized with Coronavirus disease 2019: Should we worry? Liver Int. 2020;40(8):1860-4.

7. Fan Z, Chen L, Li J, Cheng X, Yang J, Tian C, et al. Clinical features of COVID-19related liver functional abnormality. Clin Gastroenterol Hepatol. 2020;18(7): 1561-6.

8. Cai Q, Huang D, Yu H, Zhu Z, Xia Z, Su Y, et al. COVID-19: Abnormal liver function tests. J Hepatol. 2020;73(3):566-74.

9. Shao T, Tong Y, Lu S, Jeyarajan AJ, Su F, Dai J, et al. Gamma-Glutamyltransferase Elevation Is Frequent in Patients With COVID-19: A Clinical Epidemiologic Study. Hepatol Commun. 2020;0(0):1-7.

10. Zhang H, Yu-Sheng L, Gong J, Liu J, Zhang $\mathrm{H}$. Clinical characteristics and risk factors for liver injury in COVID-19 patients in Wuhan. World $\mathrm{J}$ Gastroenterol. 2020;26(31):4694-702.

11. Guo H, Zhang Z, Zhang Y, Liu Y, Wang J, Qian Z, et al. Analysis of liver injury factors in 332 patients with COVID-19 in Shanghai, China. Aging (Albany NY). 2020;12(19):18844-52.

12. Wang Y, Liu S, Liu H, Li W, Lin F, Jiang L, et al. SARS-CoV-2 infection of the liver directly contributes to hepatic impairment in patients with COVID-19. J Hepatol. 2020;73(4):807-16.

13. Chen LY, Chu HK, Bai T, Tu SJ, Wei Y, Li $\mathrm{ZL}$, et al. Liver damage at admission is an independent prognostic factor for COVID-19. J Dig Dis. 2020;21(9):5128.

14. Piano S, Dalbeni A, Vettore E, Benfaremo D, Mattioli M, Gambino CG, et al. Abnormal liver function tests predict transfer to intensive care unit and death 
58 Medical Scope Journal (MSJ), Volume 2, Nomor 2, Januari-Juni 2021, hlm. 53-58

in COVID-19. Liver Int. 2020;40(10): 2394-406.

15. Fu Y, Zhu R, Bai T, Han P, He Q, Jing M, et al. Clinical features of COVID-19infected patients with elevated liver biochemistries: a multicenter, retrospective study. Hepatology. 2020;0(0): $0-3$.

16. Chen F, Chen W, Chen J, Xu D, Xie W, Wang $\mathrm{X}$, et al. Clinical features and risk factors of COVID-19-associated liver injury and function: A retrospective analysis of 830 cases. Ann Hepatol. 2021. MarchApril; 21:100267.

17. Chu H, Bai T, Chen L, Hu L, Xiao L, Yao L, et al. multicenter analysis of liver injury patterns and mortality in COVID-19. Front Med. 2020;7:1-8.

18. Wu Y, Li H, Guo X, Yoshida EM, Mendez-
Sanchez N, Levi Sandri GB, et al. Incidence, risk factors, and prognosis of abnormal liver biochemical tests in COVID-19 patients: a systematic review and meta-analysis. Hepatol Int. 2020;14(5):621-37.

19. Kumar-M P, Mishra S, Jha DK, Shukla J, Choudhury A, Mohindra R, et al. Coronavirus disease (COVID-19) and the liver: a comprehensive systematic review and meta-analysis. Hepatol Int. 2020;14(5):711-22.

20. Adiwinata R, Irawan VR, Arifputra J, Waleleng BJ, Gosal F, Rotty L, et al. Potential of fecal-oral transmission and gastrointestinal manifestation of COVID-19. Indones J Gastroenterol Hepatol Dig Endosc. 2020;21(1):53. 